\title{
Multiculturalism in the workplace: Model and test
}

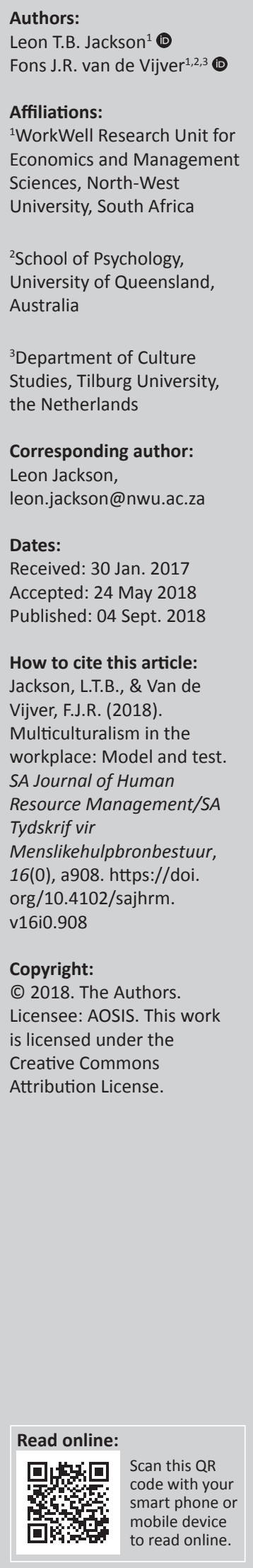

Orientation: This article addresses the role of multiculturalism in employee attitudes.

Research purpose: It proposes a model of positive features of multiculturalism in organisations and tests it in South Africa. The model postulates three levels in multiculturalism: antecedent conditions, such as multiculturalism practices and norms that define the diversity climate; mediators, such as diversity-enhancing employee attitudes; and positive work outcomes.

Motivation for the study: South Africans from diverse backgrounds hardly meet in their private spaces. Given this forced contact in the workplace and the calls for national unity and social cohesion, we propose that a workplace that is characterised by mutual respect, accommodation and tolerance for difference could have a positive impact on employee work attitudes.

Research approach/design and method: A quantitative approach was adopted using survey questionnaires that were distributed to employees selected on the basis of convenience sampling $(N=299)$ in various workplaces.

Main findings: A multi-group path analysis confirmed the validity of the model for the white, black and mixed race ethnic groups. Although the differences were negligible to medium, white groups seemed to experience a slightly more favourable multicultural environment compared to black and mixed race groups.

Practical/managerial implications: All dimension scores were well above the mid-point of the scale, which suggests that psychometrically speaking, the multicultural climate, ethnic integration orientations and employee attitudes are experienced by these employees as favourable.

Contribution/value-add: From a conceptual perspective, the model implies that the more distal variable of a multicultural climate influences employee attitudes through a set of more proximal integration attitudes and practices. From a practical perspective, an inclusive climate has more distal characteristics such as the general multiculturalism climate and more proximal characteristics such as ethnic vitality.

\section{Introduction}

We are interested in the role of multiculturalism (referring to the recognition and support of the plural nature of the society; Berry \& Kalin, 1995) in employee attitudes in the workplace. South Africa is an interesting location to study diversity in organisations, given the country's history of racial segregation and discrimination. The system of apartheid, the legal basis of this segregation and discrimination, was abolished in 1994. The promulgation of various post-1994 laws, such as the Labour Relations Act 66 of 1995 (RSA, 1995), the Employment Equity Act No 55 of 1998 (RSA, 1998) and the Basic Conditions of Employment Act No 75 of 1997 (RSA, 1997b), was aimed at demolishing discrimination, enhancing national cohesion and the creation of a rainbow nation (a term framed by Bishop Desmond Tutu to refer to the multi-ethnic composition of the South African society). These developments have resulted in increments in intercultural contacts in the workplace. However, South African employees often encounter two types of diversity in the workplace. Firstly, the business world as currently conceptualised and structured in most South African corporations is generally cast in a Eurocentric mould (Khoza, 1993), which largely resembles features of white domination of the pre-1994 era. This mould is quite different from the home culture, notably for the black groups. Secondly, because of the still rampant segregation of society, work is the only place where many South Africans meet individuals from other ethnic groups (Hofmeyr, 2006; Jackson \& Van de Vijver, 2018). Given this forced contact in the workplace, calls of the new Constitution (RSA, 1996) for national unity and social cohesion, this contribution proposes that a workplace that is characterised by mutual respect, accommodation and tolerance for difference could have a positive impact on employee work attitudes and output. 
Unfortunately, recent research results (Stoermer, Hitotsuyanagi-Hansel, \& Froese, 2017) suggest that black South Africans are still prone to become targets of workplace racial harassment and that fault lines based upon skin colour persist. Consequently, racially harassed employees report lower degrees of job satisfaction (Stoermer et al., 2017). This, in return, can lead to voluntary turnover (Porter, Steers, Mowday, \& Boulian, 1974) and decrease individual performance (Harter, Schmidt, \& Hayes, 2002). This prevents organisations from maximising their competitive edge (Earley \& Mosakowski, 2000). South African organisations need to take action to foster cooperation and trust among employees of different racioethnicities (Stoermer et al., 2017). One remedy is establishing an organisational inclusion climate (Nishii, 2013; Stoermer, Bader, \& Froese, 2016).

This contribution aims to heed this call and to encourage interdisciplinary research, and it therefore proposes and tests a model of multiculturalism in the workplace. The model of this study is based on a mediating model of acculturation (Arends-Tóth \& Van de Vijver, 2006), the interactive acculturation model (IAM) (Bourhis, Moïse, Perreault, \& Senécal, 1997) and the interactional model of cultural diversity (Cox, 1993). The model holds that multiculturalism comprises three components: antecedents defining a climate of diversity-enhancing conditions such as multicultural policies and practices as supported by the majority in the workplace, mediating conditions comprising employee (and people from his ethnic group) orientations towards integration and employee outcomes comprising subjective experiences of work success, commitment and job satisfaction. Not only does this article fill the gap in the literature regarding the role of multiculturalism in employee attitudes in the South African workplace but it also addresses the call of Bourhis et al. (1997) to investigate the role of both mainstream (multicultural or diversity-enhancing conditions or requirements at work) and minority contextual features (integration orientation at work) and attitudes simultaneously. In addition, empirical evidence on the positive effects of multiculturalism in the workplace could be just the recipe for encouraging management (currently, mainly white) to facilitate and promote diversity initiatives in South African organisations.

\section{Literature review}

\section{Models, typologies, strategies, definitions and benefits of} multiculturalism

Psychological literature on acculturation has focused on the ways in which majority attitudes towards multiculturalism impact on the acculturation strategies of migrants. The most widely cited model of acculturation has been developed by Berry (e.g. 1997, 2001, 2005, 2008, 2011). According to Berry's model, when migrants enter a new cultural environment, they are faced with two questions: (1) whether they wish to maintain their affiliation with the culture of their country of origin and (2) whether they wish to forge relations with the dominant culture of the society they are entering. Depending on how migrants respond to these two issues, they are said to employ one of four acculturation strategies: not wanting to maintain one's cultural identity but seeking contact with the dominant group (assimilation), avoidance of interaction with the dominant group and placement of value on maintaining one's original culture (separation), little possibility or interest in cultural maintenance and relating to other cultures (marginalisation) and maintenance of one's original culture while also pursuing contacts with the dominant group (integration) (Berry, 2013).

According to Ojukwu and Oni (2017), multiculturalism embodies and promotes cultural security, cultural diversity and cultural equity. Cultural security is a broad concept that encompasses cultural safety, cultural sensitivity and awareness. Cultural safety refers to the condition in which people recognise their own culture, language, customs, attitudes, beliefs and preferred ways of doing things in their social and economic environment (IACIU, 2014:6).

Multiculturalism has been policied, particularly in Europe, to create national unity in ethnic diversity (Johnson, 2015). As such, it has been criticised for essentialising culture and reifying cultural differences (Howarth \& Andreouli, in press). The criticisms multiculturalism faces are many and varied (Mason, 2018). It presupposes an essentialist conception of culture that treats cultures as static, homogeneous and bounded, with the result that multicultural policies tend to entrench traditional practices and promote the interests of established elites within cultural communities (Barry, 2001; Kukathas, 2003); that it gives unfair advantages to minority cultural and religious groups through additional funding and special provisions such as exemptions from laws and policies (Barry, 2001); that it is bad for women (Okin, 1999); and that it discourages cultural communities from integrating and encourages them to form separate parallel societies (Goodhart, 2013; West, 2013). Ironically, multicultural initiatives can produce scepticism and resentment on the part of, in particular, non-minorities (James, Brief, Dietz, \& Cohen, 2001) and criticism centres on the claim that it excludes non-minorities, threatens unity (Plaut, Sanchez-Burks, Buffardi, \& Stevens, 2007) and promotes separatism and division (Frederickson, 1997). Exclusion from organisational information and decision-making networks has been identified as one of the most significant problems facing today's diverse workforce (Fernandez, 1991; Morrison \& Von Glinow, 1990; O'Leary \& Ickovics, 1992). The inclusionexclusion experience of diversity is one that has deep social-psychological roots for human beings (Baumeister \& Leary, 1995).

This is in contrast to the use of the term to describe a situation in society where diversity is widely accepted and valued, by all ethnocultural groups, and where cultural groups maintain their ethnic and cultural distinctiveness while still participating in the daily life of greater society (Berry, 2013; Sam, 2006). In addition, Howarth and Andreouli (in press) propose that multiculturalism should be studied as a social representation, that is, a collectively shared system of 'values, ideas and practices' (Jovchelovitch 2007; Moscovici 1973, p. xiii; 2000; Wagner \& Hayes, 2005). 
Ramakrishna (2013, p. 100) argues that multiculturalism is 'the representation of difference'. By this, multiculturalism means accepting and tolerating differences in cultural identities and promoting ways of peaceful coexistence. Rosado (1996) explicitly defines multiculturalism as:

a system of beliefs and behaviours that recognizes and respects the presence of all diverse groups in an organization or society, acknowledges and values their socio-cultural differences, and encourages and enables their continued contribution within an inclusive cultural context which empowers all within the organization or society. (p. 2)

Therefore, multiculturalism can be described as a behavioural pattern that appreciates, tolerates and promotes multiple cultures and identities situated within the confines of a particular community. These explanations infer that multiculturalism is a reactionary movement or ideology purposed to resolving the challenges of colour difference, cultural diversity and social inequality through an attitude of acceptability, hospitality, tolerance and love (Olanrewaju, Loromeke, \& Adekoye, 2017).

In general, intercultural contact of higher quality predicted more positive intergroup attitudes, trust, more positive perceptions of out-group intentions in working towards peace (Tropp et al., 2017). More specifically, managing and valuing diversity enhances the performance (Choi \& Rainey, 2010; Mazibuko \& Govender, 2017). Workplace diversity is associated with higher organisational benefits (Joubert, 2017). For instance, cultural diversity is associated with organisational advantages, such as strengthening the organisation's culture, improving the company's global reputation, increasing creativity and innovation or building loyalty among customers of different origins (Cox \& Blake, 1991; Franken, 2015; Shen, Chanda, D’Netto, \& Monga, 2015; Thomas \& Ely, 1996). It is also associated with increases in productivity, goal attainment, creativity, client focused services and an interesting work environment (Joubert, 2017) as well as work team cohesion (Cashmore, 2003; Trivedi, 2008). In addition, when diversity is managed effectively, employees learn more about each other so that communication is improved, with less stereotyping and discrimination among the employees (Joubert, 2017). Organisations promoting initiatives based on a multicultural ideology can be expected to be particularly attractive to minorities, because diversity is acknowledged and retained (Verkuyten, 2005).

Nonetheless, not all people might experience the workplace positively (Jackson \& Van de Vijver, 2018). For instance, women of all races are overrepresented in pink-collar jobs (Jaga, Arabandi, Bagraim, \& Mdlongwa, 2017). Sue and Capodilupo (2008) reported that women experience a variety of gender microaggressions and discrimination that undervalue their work contributions. Older workers were likely to be channelled to lower paid jobs than young workers, potentially affecting their standard of living (Drydakis, MacDonald, Chiotis, \& Somers, 2018). About 16\% - 68\% of lesbian, gay, bisexual and transgender individuals reported experiencing employment discrimination, with $41 \%$ being harassed at work and gay men earned 10\% - 32\% less than equally qualified heterosexual men (Badgett, Lau, Sears, \& Ho, 2007). Durrheim and Talbot (2012) and Moloto, Brink and $\mathrm{Nel}$ (2014) reported racial stereotypes prevalent among all four South African race groups (i.e. black, white, Indian and mixed race). Another study found that stereotypes also exist about both race and gender groups occupying managerial positions (Booysen \& Nkomo, 2010).

Given the challenges above, efforts must be speeded up to provide answers to the problematic issues that arise as a result of frequent intercultural interaction in the workplace and in society. Interdisciplinary research could provide some of the answers that we so desperately need. Service research is also especially apt for interdisciplinary as service is not developed by any one function in a company; it is a purpose in some way for everyone across the organisation regardless of where they are working. It is strange then that we have not advanced further on interdisciplinary research, particularly because it has been in focus for a long time in the field (Gustafsson \& Bowen, 2017). Never before has cooperative research been as necessary among scholars and practitioners as in the case of inclusion (Wooten \& James, 2008). The greatest advances in human resources (HR) practices have resulted from the joint activities of scholars and practitioners (Shore, Cleveland, \& Sanchez, 2018).

\section{A model of multiculturalism in the workplace}

It is a novel feature of this contribution that it studies diversity from an acculturation perspective, as acculturation is a productive way of examining adjustment processes faced by individuals who come into continuous contact with other cultural backgrounds (Berry, 1997). This theoretical framework combines a mediation model of acculturation in the broader society (Arends-Tóth \& Van de Vijver, 2006) and in the workplace (Jackson, Van de Vijver, \& Ali, 2012). Antecedents in the model, called multiculturalism or diversity-enhancing conditions, refer to contextual conditions that define the climate of the workplace vis-à-vis diversity, such as descriptive norms and practices about the need to acknowledge, respect, appreciation of multiculturalism and tolerance of culturally diverse group. Mediating variables, called ethnic integration, refer to the various aspects that, as a consequence of a positive diversity climate, promote integration that refers to retaining your own identity and freely interacting with people from different ethnic backgrounds. Integration is a combination of attitudes and practices that maintain the own ethnic identity (such as ethnic vitality) and attitudes and practices that promote multiculturalism (interaction and contact with people from your own and other ethnic backgrounds) and the need to adopt a multicultural identity (such as pressure by co-ethnics to embrace multiculturalism at work). Outcomes in the model are represented by employee attitudes such as job satisfaction, organisational commitment (psychological diversity outcome indicators) and perceived subjective experience of work success (sociocultural diversity outcome indicator). 


\section{Antecedent conditions}

The coexistence and integration of the diverse cultures represented in the workforce are important in multiculturalism. Multiculturalism conditions have an impact on intercultural interaction and the adjustment in the workplace. Research has recently confirmed contextual influences (such as the degree of multiculturalism in the workplace) on ethnic diversity orientations; ethnic vitality and an integration orientation play a crucial role in these orientations, which are supposed to influence adaptation and intergroup relationships (Jackson \& Van de Vijver, 2018; Jackson et al., 2012). As antecedent or diversity-enhancing conditions, this study focuses on perceived institutional or majority support for multiculturalism and mainstream tolerance.

Perceived multicultural norms refer here to rules and codes of conduct that emphasise acknowledgement, respect and appreciation of cultural differences in the workplace (e.g. the majority members in the organisation believe that people from different ethnic backgrounds should be respected), while perceived multicultural practices refer to the actual coemployee behaviours vis-à-vis diversity in the workplace (e.g. the majority members in the organisation respect people from different ethnic backgrounds). According to Berry (2006), although support for multiculturalism may be conceptually similar to tolerance, multiculturalism attitudes are more related to the idea that diversity is a resource for a society, and that all ethnocultural groups should be mutually accommodating to obtain harmonious relationships in a culturally plural society. Empirically, support for multiculturalism was correlated with dominant group members' tolerance (Berry, 2006; Jackson \& Van de Vijver, 2018; Jackson, Van de Vijver, \& Biela, 2013a), while support for multiculturalism strongly predicted social tolerance (Van der Noll, Poppe, \& Verkuyten, 2010).

Perceived mainstream tolerance refers to the condition of not being uncomfortable with others' existences with regard to different language, gender, religion, belief and attitude (Sahin, 2011). Tolerance has also been demarcated as a preparedness to give up unlikable thoughts or groups (Gibson, 2006). Contemporary scholars outline tolerance as diversity esteem, openness, inclusiveness of all ethnicities, races and walks of life and cultivating oneself to respect others (Corneo \& Olivier, 2009; Florida, 2003; Ramadan, 2010). Tolerance here refers to acknowledgement, acceptance and lenience towards cultural differences. Tolerance is an attitude towards social equality and egalitarianism (Berry, 2006). Ethnic tolerance is opposite to ethnocentrism that tends to favour one's in-group over out-groups (Berry \& Kalin, 1995), whereas social egalitarianism involves intolerance for social dominance orientation, supporting equal opportunities and rights (Berry, 2006). Multicultural practices and norms and mainstream tolerance in the workplace are associated with lower levels of physical and psychological ill health as well as increased subjective experiences of work success (Ait Ouarasse \& Van de Vijver,
2004; Jackson \& Van de Vijver, 2018; Jackson et al., 2012) and satisfaction with life (Jackson et al., 2013a). Research also found that a multicultural ideology was related to an integration strategy (Hui, Chen, Leung, \& Berry, 2015).

\section{Mediating conditions: Ethnic integration norms at work}

According to Bourhis et al. (1997), a common shortcoming of acculturation models is the lack of importance given to how the host community and the integration policy of the state can shape especially the acculturation preferences of minority group members. The IAM, proposed by Bourhis et al. (1997), suggests that the acculturation orientations of ethnic minority members are related to the acculturation orientations of host majority members and should be emphasised and included in empirical studies. Integration involves some degree of maintenance of the home culture, while at the same time, members of an ethnic cultural group seek to participate as an integral part of the larger social (diverse) network (Berry, Poortinga, Breugelmans, Chasiotis, \& Sam, 2011). Ethnic integration norms at work (Jackson et al., 2012), individual integration orientation (Jackson \& Van de Vijver, 2018; Jackson et al., 2012) and ethnic vitality (Ait Ouarasse, 2004) are the variables from the minority context that have been reported to bear on acculturation outcomes that are considered in this contribution.

In this study, perceived ethnic integration norms at work refer to the pressure or expectation from own ethnic members to retain one's own culture, but also to participate in and adopt the culture of the workplace, which combines a largely European business culture and a plural ethnic culture among colleagues (the latter concept is known in South Africa as the rainbow nation). Integration is often seen as the best way for an individual to deal with differences between important cultures for the person such as the home and diverse culture of the workplace (Berry, 2003). Positive relations between ethnic integration norms, and multiculturalism, mainstream tolerance, subjective experiences of success at work as well as lower levels of ill health, have been reported (Ait Ouarasse, 2004; Jackson et al., 2012).

Individual integration acculturation orientation, in Berry's (1997) bi-dimensional model, refers to an immigrant's preference to maintain his own culture, but also to participate in the mainstream culture. In the context of the present study, integration refers to individual preferences in the workplace to have contacts with own but also other ethnicities. Berry (1997) has argued that integration is the individual-level orientation that corresponds to multiculturalism at organisational or societal level. Research has often shown that integration is the orientation most favoured by minority members (Pham \& Harris, 2001; Zagefka \& Brown, 2002). A recent study confirmed positive relations between an individual integration acculturation orientation and multiculturalism, mainstream tolerance, ethnic integration norms at work and subjective experiences of work success as well as a negative relation with physical and psychological ill health (Jackson \& Van de Vijver, 2018; Jackson et al., 2012). 
The concept of ethnic vitality, adapted from linguistics (Harwood, Giles, \& Bourhis, 1994), refers to ethnic institutions that can support the diversity process, such as the availability of places of worship, shops, recreational opportunities and educational resources for specific ethnic groups (Adelman, 1988; Galchenko, 2006; Malewska-Peyre, 1982). Perceived ethnic vitality refers in the present study to the availability of services for diverse groups in an organisation, such as availability of and catering for ethnic specific food and freedom to engage in ethnic practices (language usage, clothing and prayers), which are the consequences of support for a multicultural climate, as implemented in diversity policies. A minority that is vital and supportive acts as both springboard from which minority individuals can deal with the mainstream culture, which is seen in the positive effect on relationships and work success, and as a safety net that provides support to deal with negative acculturation experiences, which is performed indirectly via relationships with co-ethnics (Jackson, Van de Vijver, \& Molokoane, 2013). Positive relations between perceived ethnic vitality, social relations, school success, mental health (Ait Ouarasse, 2004), multiculturalism, tolerance and approach coping style and work success have been confirmed in the research (Jackson et al., 2013b).

\section{Diversity outcomes: Employee attitudes and performance}

In the acculturation literature, outcomes are often grouped under two major types: psychological outcomes and sociocultural outcomes (Ward, Bochner, \& Furnham, 2001). The psychological outcomes of acculturation are mainly studied in the stress and coping tradition and refer to mental health and general satisfaction with life in the host milieu. Sociocultural adaptation, on the other hand, is studied in the culture learning tradition, and is mainly a matter of successful participation in the host society. In the present study, the focus is on employee attitudes, such as job satisfaction and organisational commitment, as well as subjective experiences of work success as indicators of psychological and sociocultural diversity outcomes, respectively. Psychological adaptation was positively correlated with an integration strategy and multicultural ideology, while sociocultural adaptation was positively correlated with an integration strategy (Hui et al., 2015).

Job satisfaction and organisational commitment represent psychological diversity outcome indicators in this contribution. Addressing the needs or challenges of a diverse workforce is important for maintaining positive work attitudes in employees, particularly job satisfaction (Stoermer et al., 2017), which is one of the central determinants of crucial work-related outcomes, such as organisational commitment, employee performance or turnover (Zimmerman, 2008). In their meta-analysis on the effects of perceived organisational support (POS), Rhoades and Eisenberger (2002) showed the beneficial effects of POS on several employee outcomes, for example, affective commitment, job satisfaction and extrarole performance. Perceived organisational support signals to employees that the organisation is taking care of their needs beyond legal requirements. The positive association between multiculturalism and job satisfaction has been confirmed empirically in South Africa (Jackson et al., 2012). In addition, research has confirmed that women's minority status in the mining industry places them at greater risk of poorer mental health and job satisfaction than their male colleagues because of their lower social status, less social support and less social integration in the industry (Penhaligon, Louis, \& Restubog, 2013; Seeman, 1996; Skaalvik \& Skaalvik, 2011; Thoits, 2011).

The effect of diversity management on employees' affective commitment can partially be explained by its impact on the inclusiveness of the organisational culture (Ashikali \& Groeneveld, 2015). Perceptions of inclusion and fair treatment, which are features of multiculturalism, have been found to predict both organisational commitment and job performance (Cho \& Mor Barak, 2008). Moreover, models of inclusion treat affective commitment as an outcome of diversity management for all employees because they rest upon the assumption that individuals need to fulfil their need for belongingness and uniqueness. This is, in fact, the goal of diversity training: to select and effectively manage diverse employees by valuing their uniqueness while increasing their sense of belonging to and identifying with the organisation (Ashikali \& Groeneveld, 2015; Shore et al., 2011). Organisations endorsing a diversity climate should be regarded as serving employees from all ethnicities (McKay et al., 2007).

Perceived subjective experience of work success is a sociocultural diversity outcome indicator in this study, which refers to the extent employees perceive that they are meeting and exceeding standards, and that they are performing well at work. The concept also refers to the respect that employees earn from co-workers as consequences of being successful at work. Work success relates positively with multiculturalism and tolerance (Jackson \& Van de Vijver, 2018; Jackson et al., 2012, 2013) and negatively with diversity-inhibiting conditions, such as subtle racism, discrimination and segregation demands (Jackson \& Van de Vijver, 2018; Jackson, Van de Vijver, \& Burckard, 2011; Jackson et al., 2013a).

The aim of the present study was to test the feasibility of a conceptual model of multiculturalism in the workplace. More specifically, the following hypothesis was tested:

- Hypothesis 1: The same mediation model of multiculturalism (with positive associations between positive diversity conditions or antecedents, mediating variables and employee outcomes) holds for the white, black and mixed race groups.

\section{Group differences in support for multiculturalism in South Africa}

Recent national and international surveys of ethnic differences in opposition to such policies suggested an element of group self-interest at play in the policy attitudes (Durrheim, 2010; Van de Vijver, Breugelmans, \& SchalkSoekar, 2008). Members of the group who had most to gain from the policies (usually the groups with the least power 
in society) rated them most favourably, whereas members of the group who had most to lose rated the policies most negatively. It is argued that this type of reasoning does not apply to South Africa. White people still remain in a much stronger economic position compared to black people in that they are still the dominant group in the economic sense, being the most affluent group with the highest positions in organisations; therefore, white people are served best by a policy that does not threaten their position. Given the poor progress of representation of black people and women in top positions in the organisation, it is argued that extant business practices that still favour white people will not threaten the dominant position of the white group in the South African workplace. It is only through measures of affirmative action (AA) and Broad Base Black Economic Empowerment (BBBEE) policies and other forms of positive discrimination or preference to previous disadvantaged groups (black people, women and the people with disabilities) that the dominant position of the white groups is challenged.

It is not surprising that once the beneficiaries and power wielders of the apartheid state, Afrikaners in particular, found that their 'worldview ... imploded' (Steyn 2004, p. 143), and that the opposition to these measures of white groups is strong (Herman, 2000). This is confirmed in studies showing that, in the aftermath of the racial state's demise, white communities struggle to come to terms with their 'new' minority status (Alsheh \& Elliker 2015), try to maintain white privilege in the face of black power (Steyn \& Foster 2008) or work to 'rehabilitate an ethnic whiteness in distress' (Blaser \& Van der Westhuizen 2012, p. 385).

The reality, however, paints a different picture. As a result of their dominant position in the workplace, white people still experience the recent South African diverse workplace more positive compared to non-white people despite recent legislative changes such as the Employment Equity Act (RSA, 1998) and the use of AA policies that favour non-white people in both private and public institutions (Jackson et al., 2011, 2012). This is also supported by the overrepresentation of white people in top management positions in the South Africa (Department of Labour, 2017). Africans constituted less than $14.4 \%$ of top management in 2016, yet they constitute $78 \%$ of the workforce of the country. Mixed race constituted less than $4.9 \%$ of top management in 2016, yet they constitute $9.8 \%$ of the workforce of the country. Indians constituted less than $8.9 \%$ of top management in 2016, yet they constitute $2.8 \%$ of the workforce of the country. White groups constitute $68.5 \%$ of top management in 2016, yet they constitute only $9.5 \%$ of the workforce (Department of labour, 2017). Another aim of this study was for ethnic group differences in components of the model. More specifically, given the aforementioned, we tested the following hypothesis:

- Hypothesis 2: White employees score significantly higher in multiculturalism and mainstream tolerance, ethnic vitality, ethnic integration and positive employee attitudes compared to black employees.

\section{Research methods Research approach}

This research began with a quantitative approach, followed by a cross-sectional survey design whereby a sample was drawn from a population at one point in time, and this sample was used to obtain the research objectives. Cross-sectional designs are appropriate where groups of participants, at various stages of development, are studied simultaneously, whereas the survey technique of data collection gathers information from the target population by means of questionnaires (Burns \& Grove, 1993). This design is used to assess interrelationships among variables within the population. Survey questionnaires were distributed to employees selected on the basis of convenience sampling in various workplaces in South Africa.

\section{Procedure}

The Economic and Management Faculty's Ethics Committee of North-West University approved the study. These employees were mostly the colleagues and co-workers of network members and acquaintances. In addition, permission was acquired through formal verbal requests to line managers during visits to various workplaces to gather data from employees not acquainted with the researcher filling out the questionnaires. Participants completed consent forms. The purpose, anonymity and voluntary nature of the research and its advantages were explained to prospective participants after permission was granted during lunch break briefings. Participants were given two weeks to complete the questionnaires, which could be dropped in a sealed box in the HR section that was later collected by the researcher.

\section{Sampling and participants}

Using convenience sampling, participants from different workplaces in South Africa were approached. Characteristics of the participants are presented in Table 1. The sample $(N=299)$ consisted mainly of female employees $(55.35 \%)$ in the age range of 26-33 years (40.67\%). Approximately one-third $(34.56 \%)$ were mixed race employees, $33.33 \%$ were black employees, $23.55 \%$ were white employees, $7.95 \%$ were

TABLE 1: Participant characteristics.

\begin{tabular}{llcc}
\hline Item description & Category & Frequency & Percentage \\
\hline Gender & Male & 135 & 45.2 \\
Age & Female & 164 & 54.8 \\
& $18-25$ & 74 & 24.7 \\
& $26-33$ & 120 & 40.1 \\
& $34-41$ & 72 & 24.1 \\
Ethnic group & $42-49$ & 22 & 7.4 \\
& $50-60$ & 11 & 3.7 \\
\multirow{5}{*}{ Educational qualifications } & White & 77 & 25.8 \\
& Black & 109 & 36.5 \\
& Mixed race & 113 & 37.8 \\
& Grade 12 & 96 & 32.1 \\
& Certificate & 73 & 24.4 \\
& Diploma & 71 & 23.7 \\
& Degree & 34 & 11.4 \\
\hline
\end{tabular}


Indian and 0.61 indicated other; $30.89 \%$ of the employees held a grade 12 or National Senior Certificate (corresponding to completed secondary school or higher).

\section{Measurements}

Some instruments with well-established psychometric properties used in other cultural contexts were adapted (Ait Ouarasse \& Van de Vijver, 2004). Adaptations involved replacing the original ethnic groups of the scale, Dutch and Moroccan-Dutch, with South African and its ethnic groups, respectively. All diversity scales follow a five-point Likert format ranging from strongly agree (1) to strongly disagree (5) and item scores were reversed before the analyses so that higher scores reflect a higher standing on the target construct.

\section{Mainstream domain instruments}

- Perceived multicultural norms: This six-item scale is an adaptation of Ait Ouarasse and Van de Vijver (2004). This instrument measures the participant's multiculturalism values and attitudes on a five-item measurement scale that defines the participant's experiences of the majority of his or her co-workers' attitudes, cultural diversity acceptance, racial integration and equality within the workplace. An example item is: 'I think most of my coworkers from other cultures are most welcoming people'.

- Perceived multicultural practices: This scale is an adaptation of the scale by Ait Ouarasse and Van de Vijver (2004) and contains six items that measure the behaviour of actual multiculturalism and the occurrence of multicultural practices among the majority of co-workers within an organisation. An example item is 'My coworkers generally show respect for other cultures in our organization'.

- Perceived mainstream tolerance: This scale is an eightitem measure adapted from Ait Ouarasse and Van de Vijver (2004) and evaluates the participants' perceptions of the majority of co-workers and their attitudes to ethnic difference within the workplace and their general acceptance of cultural diversity and minority ethnic group activity. A sample items is 'I think that most of my co-workers accept the fact that we have different cultures'.

\section{Mediating variables}

- Ethnic vitality: Ethnic vitality is a six-item scale adapted from Ait Ouarasse and Van de Vijver (2004) that measures organisational institutions' source of support and educational resources for acculturation processes taking place. A sample item is 'The cafe caters (makes provision) for my cultural food in our organisation'.

- Integration norms at work: This six-item scale (Jackson et al., 2012) measures the individual's own ethnic group's preference and expectation for integration of their members within the organisation as part of diversity. It expresses wishes from co-ethnics to interact and make contact with members form other ethnic groups. Items are phrased as positive statements; a sample item is
'Most members of my cultural group want me to show my cultural values and to respect those of others'.

- Integration orientation: This three-item scale measures the intended responses from employees regarding their attitudes towards integration, which involves adaptation and adoption of the dominant culture while not relinquishing their own. Sample items include 'I prefer social contact and interaction with members of ALL South African groups irrespective of ethnicity as well as with members of my own ethnic group'.

\section{Psychological and sociocultural diversity outcomes}

- Psychological outcome - The Minnesota Satisfaction Questionnaire (MSQ): A short form developed by Weiss, Dawis, England and Lofquist (1967) was used in the present study. The MSQ is a 20-item scale that was used to assess the participants' intrinsic and extrinsic satisfaction with their jobs. Sample items include 'The way my job provides for steady employment' and 'The chances for advancement on the job'.

- Psychological outcome - Organisational commitment: This eight-item scale was developed for the study to measure an individual's affective commitment to his or her current workplace. Sample items include 'I am committed to this organization' and 'I am proud of this organization'.

- Sociocultural diversity outcome - Work success: This 14-item scale was developed by Ait Quarasse and Van de Vijver (2004). The scale measures sociocultural outcomes and includes punctuality, status, and recognition at work and task completion. Sample items include 'I always meet deadlines in my work' and 'I do my work well enough to be respected by my co-workers'.

\section{Data analysis}

We applied multi-group path analysis (using AMOS version 24) to test for mediation effects of integration in the link between diversity conditions and employee outcomes. The mediation model was based on the reasoning that more distal variables (antecedent) conditions influence more proximal variables (diversity orientation), which, in turn, influence employee attitudes. We conducted a closer examination of the direct and indirect effects to evaluate their relative sizes, using the bootstrap procedure as implemented in the AMOS programme. Moreover, we computed a multivariate analysis of variance (MANOVA) to examine racial group differences in their experiences of workplace diversity and employee attitudes. Cohen's $d$ values were used to gauge the size of the ethnic differences.

\section{Results}

The results of this study are presented in three parts. We firstly examined the psychometric properties of the scales by conducting exploratory factor analyses (EFAs) and confirmatory factor analyses (CFAs) to examine the dimensionality and invariance of the scales and items in the 
black, mixed race, and white groups using AMOS and SPSS software. We also computed internal consistencies. Secondly, we tested if our hypothesised multicultural model in the workplace would fit our data for the three groups of employees using multi-group analyses. Thirdly, we test group differences between black and white employees in the experiences of antecedents and intervening variables and employee attitudes.

\section{Psychometric properties}

The results obtained from EFAs indicated that all scales used were unifactorial; proportions of explained variance by the first factor obtained in this study were as follows: $43.25 \%$, $47.78 \%$ and $43.52 \%$ of the variance in perceived multicultural norms for white, black and mixed race employees, respectively; $43.21 \%, 44.57 \%$ and $43.275 \%$ in perceived mainstream tolerance for white, black and mixed race employees, respectively; $56.40 \%, 46.25 \%$ and $54.38 \%$ in perceived multicultural practices for white, black and mixed race employees, respectively; $56.73 \%, 64.10 \%$ and $53.92 \%$ in an individual integration orientation for white, black and mixed race employees, respectively; $31.92 \%, 35.03 \%$ and $44.16 \%$ in perceived ethnic vitality at work for white, black and mixed race employees, respectively; $60.71 \%, 54.73 \%$ and $61.28 \%$ in perceived ethnic integration demands at work for white, black and mixed race employees, respectively; $39.30 \%, 31.53 \%$ and $36.96 \%$ in job satisfaction for white, black and mixed race employees, respectively; $62.44 \%, 62.44 \%$ and $48.45 \%$ in organisation commitment for white, black and mixed race employees, respectively; and $43.99 \%, 36.89 \%$ and $39.86 \%$ in subjective experiences of work success for white, black and mixed race employees, respectively. Next, Cronbach's alpha coefficients and the relationships between the different variables focused on in this study were examined. An inspection of Table 2 shows that all the alpha coefficients obtained for the constructs measured, except for multicultural norms (white and mixed race people), ethnic vitality at work (white and black people) and individual integration orientation (white people) were lower than the guideline of 0.70 (Nunnally \& Bernstein, 1994).

We then conducted invariance analyses to test scalar invariance. We conducted such analyses for each scale separately. The common approach to test for invariance is to employ CFA. However, for some of our longer measures, we did not have a sufficient sample size made to use CFA. We therefore opted for an EFA approach followed by differential item functioning analysis using regressions.

Over the past decade, applied researchers have argued that from a practical perspective, the $\chi^{2}$-difference test represents an excessively stringent test of invariance and particularly in the light of the fact that Structural Equation Modelling models at best are only approximations of reality (MacCallum, Roznowski \& Necowitz, 1992). Consistent with this perspective, Cheung and Rensvold (2002) reasoned that it may be more reasonable to base invariance decisions on a difference in CFI $(\triangle \mathrm{CFI})$ rather than on $\chi^{2}$ values. Based on a rigorous Monte Carlo study of several goodness-of-fit indices, Cheung and Rensvold (2002) proposed that evidence of noninvariance be based on a difference in CFI values larger than 0.01. The model that is taken to be invariant is then the most restrictive model for which the change in CFI value (compared to the previous, less restrictive model) is less than 0.01 . We also examined changes in Tucker-Lewis index (TLI) and root mean square error of approximation (RMSEA) (the same critical values of 0.01 have been proposed), as well as values of Akaike information criterion Akaike information criterion (AIC) (the best fitting model is the model with the lowest AIC value). We tested configural, metric and scalar invariance (the latter addresses item bias or differential item functioning), followed by tests of the invariance of path coefficients (structural weights), error components of the latent variables (structural residuals) and error components of the observed variables (measurement residuals).

\section{A test of the multiculturalism model}

In order to investigate the mediating role of ethnic integration in the relations between multiculturalism and positive employee attitudes at work, structural equation modelling was performed using AMOS 24; correlations of the components of the model are presented in Table 2. In this model (see Figure 1), a latent diversity climate variable, labelled multicultural climate that is measured by three positive multiculturalism conditions, namely multicultural norms, multicultural practices and mainstream tolerance, was found to impact on a single latent variable (positive employee attitudes at work) that was measured using three indicators,

TABLE 2: Descriptive statistics and correlations between multiculturalism and integration characteristics and outcomes.

\begin{tabular}{|c|c|c|c|c|c|c|c|c|c|c|c|}
\hline Variables & $\alpha(1)$ & $\alpha(2)$ & $\alpha(3)$ & 1 & 2 & 3 & 4 & 5 & 6 & 7 & 8 \\
\hline Multicultural norms & 0.67 & 0.77 & 0.67 & - & - & - & - & - & - & - & - \\
\hline Multicultural practices & 0.76 & 0.75 & 0.79 & $0.44 * *$ & - & - & - & - & - & - & - \\
\hline Tolerance & 0.83 & 0.76 & 0.82 & $0.54 * *$ & $0.63 * *$ & - & - & - & - & - & - \\
\hline Ethnic vitality at work & 0.56 & 0.62 & 0.74 & $0.27 * *$ & $0.37 * *$ & $0.35 * *$ & - & - & - & - & - \\
\hline Ethnic integration demands at work & 0.87 & 0.83 & 0.87 & $0.41 * *$ & $0.58 * *$ & $0.51 * *$ & $0.53 * *$ & - & - & - & - \\
\hline Individual integration orientation & 0.61 & 0.72 & 0.57 & $0.16 * *$ & $0.27 * *$ & $0.18 * *$ & $0.13^{*}$ & $0.32 * *$ & - & - & - \\
\hline Organisation commitment & 0.85 & 0.85 & 0.72 & $0.14 *$ & $0.29 * *$ & $0.14 *$ & $0.19 * *$ & $0.30 * *$ & $0.11 *$ & $0.24 * *$ & - \\
\hline Subjective experiences of work success & 0.89 & 0.86 & 0.87 & $0.29 * *$ & $0.28 * *$ & $0.21 * *$ & $0.17 * *$ & $0.30 * *$ & $0.29 * *$ & $0.26 * *$ & $0.28 * *$ \\
\hline
\end{tabular}

(1), white people; (2), black people; (3), mixed race people.

$*, p<0.05 ; * *, p<0.01$.

$\alpha$, Cronbach's alpha coefficients 
namely organisational commitment, job satisfaction (psychological outcomes) and work success (sociocultural outcomes) through a latent variable (ethnic integration) that was measured using three indicators, namely ethnic integration norms, ethnic vitality and an individual integration acculturation orientation. The conceptual model used in this study considers antecedent conditions, ethnic intervening variables and positive employee attitudes at work as outcomes of a multiculturalism model.

The similarities and differences between the white, black, and mixed race ethnic groups were explored by testing the fit of a hierarchy of models with increasing constraints on the number of invariant parameters (see Table 3). An inspection of Table 3 revealed that the structural residuals model (see Figure 1) was the most restrictive model with a good fit: $\chi^{2}(115, N=299)=$ 156.99, $p<0.01 ; \chi^{2} / d f=1.37$ (recommended $\leq 3.00$ ). Other indices confirmed the good fit of the model: The TLI was 0.94 (recommended $\geq 0.90$ ), comparative fit index (CFI) was 0.94 (recommended $\geq 0.90$ ), AIC was 250.99 (the lowest of all AIC values) and the RMSEA was 0.04 (recommended $\leq 0.06$ ). The results of the structural residuals model are presented in Figure 1. In this model, the regression coefficients of the

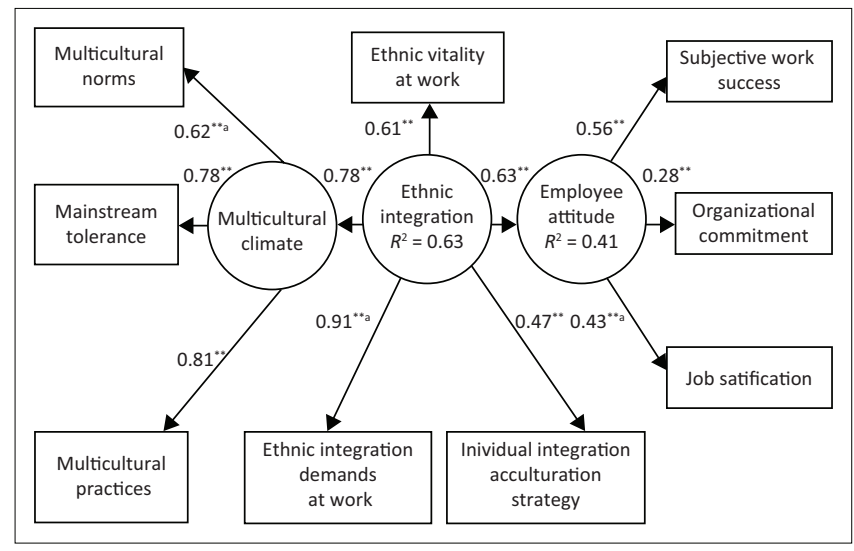

$*, p<0.05 ; * *, p<0.01$

a, parameter was fixed (as 1 ) in the input path diagram.

FIGURE 1: A model for multiculturalism at work. antecedent multicultural conditions and factor loadings to predict employee attitudes at work, through ethnic integration, the latent variable, as a mediating variable, are invariant across black, mixed race and white groups. The path from multicultural climate to ethnic integration was positive and significant. Similarly, the path from ethnic integration to employee attitude at work was also positive and significant. This suggests that climate, ethnic integration and output are related in the expected way. Employees who experienced a more positive multicultural climate also reported increased ethnic integration and better employee attitudes at work; as can be derived from the large standardised path coefficients, the associations between multicultural climate and ethnic integration and between the latter and outcomes were strong. We can therefore conclude that a multicultural climate is important for ethnic integration and employee attitudes at work.

\section{Mediating effects of ethnic integration}

The hypothesised model is a mediation model in which multicultural conditions that are markers of a multicultural climate in an organisation influence an ethnic integration, which can be associated with an inclusive, colour-blind orientation, which, in turn, affects employee attitudes at work. There was a full mediation in our model. Although we started with this more parsimonious model, there are no theoretical reasons to exclude partial mediation. We performed a closer examination of the direct and indirect effects to evaluate their relative sizes. We computed the significance of mediation effects by using the bootstrap procedure $(90 \%$ bias-corrected Confidence Interval (CI) using 200 samples) as implemented in the AMOS programme. The results of the mediation analysis can be found in Table 4. Multicultural conditions therefore exert indirect and significant influence on psychological and sociocultural diversity outcomes (job satisfaction and organisational commitment as well as the subjective experience of work success). It can be concluded that ethnic integration fully mediates the path from multiculturalism conditions to psychological and sociocultural diversity outcomes and that multiculturalism conditions show significant indirect associations with our outcomes.

TABLE 3: Results of the multi-group structural equation model analysis.

\begin{tabular}{|c|c|c|c|c|c|c|c|}
\hline Model & $\chi^{2} / d f$ & AIC & TLI & CFI & RMSEA & $\Delta \chi^{2}$ & $\Delta d f$ \\
\hline Unconstrained & $1.33^{*}$ & 274.01 & 0.95 & 0.96 & 0.03 & - & - \\
\hline Measurement weights & $1.36^{*}$ & 268.55 & 0.94 & 0.95 & 0.04 & 18.54 & 12 \\
\hline Measurement intercepts & $1.41 *$ & 262.09 & 0.93 & 0.94 & 0.04 & 29.54 & 18 \\
\hline Structural weights & $1.38^{*}$ & 260.16 & 0.93 & 0.93 & 0.04 & 6.06 & 4 \\
\hline Structural residuals & $1.33^{*}$ & 250.99 & 0.94 & 0.94 & 0.04 & 2.82 & 6 \\
\hline Measurement residuals & $1.61 * *$ & 268.12 & 0.91 & 0.90 & 0.05 & $53.13 * *$ & 18 \\
\hline
\end{tabular}

AGFI, adjusted goodness-of-fit index; TLI, Tucker-Lewis index; CFI, comparative fit index; RMSEA, root mean square error of approximation; AIC, Akaike information criterion.

$*, p<0.05 ; * *, p<0.01$.

TABLE 4: Mediation effects of integration (standardised effects).

\begin{tabular}{|c|c|c|c|c|c|c|c|c|c|}
\hline \multirow[b]{3}{*}{ Predictor } & \multicolumn{9}{|c|}{ Dependent variable } \\
\hline & \multicolumn{3}{|c|}{ Job satisfaction } & \multicolumn{3}{|c|}{ Organisational commitment } & \multicolumn{3}{|c|}{ Work success } \\
\hline & Direct & Indirect & Total & Direct & Indirect & Total & Direct & Indirect & Total \\
\hline Multiculturalism & - & 0.21 & 0.21 & - & 0.26 & 0.26 & - & 0.27 & 0.27 \\
\hline Ethnic integration & - & 0.26 & 0.26 & - & 0.33 & 0.33 & - & 0.33 & 0.34 \\
\hline Employee attitudes & 0.43 & - & 0.43 & 0.53 & - & 0.53 & 0.56 & - & 0.56 \\
\hline
\end{tabular}

Note: Empty cells (-) refer to effects that are zero in the model. All reported effects are significant, $p<0.01$. 


\section{Comparisons of ethnic groups}

An MANOVA was then carried out with ethnicity (three levels: black, mixed race and white) as an independent variable and the mean scores of the scales as dependent variables. The multivariate effect of ethnicity bordered on significance (Wilks' $\Lambda=0.917, F(18,576)=1.422, p=0.11)$. The mean scores of the scales per ethnic group are presented in Table 5 . The only significant univariate effect was found for ethnic integration demands at work $(F[2,296]=3.643, p=0.03)$, ethnic vitality $(F[2,296]=2.685, p=0.07)$, an individual acculturation orientation $(F[2,296]=3.118, p=0.05)$ and subjective experiences of work success $(F[2,296]=2.842, p=0.06)$. White employees experienced higher on multicultural norms and practices as well as tolerance and ethnic vitality at work, and preferred an individual integration acculturation orientation and subjective experiences of work success and more at work compared to black and mixed race employees in this study. It also appears that mixed race employees experience more ethnic integration demands at work compared to white and mixed race employees.

The last column presents Cohen's $d$ values, which gauges the size of the ethnic differences. Only negligible and small effect sizes were observed. Although the impact of social desirability cannot be ruled out, our data suggest that multiculturalism is relatively well supported by both groups, and that the attitudes among employees are conducive for establishing and maintaining good intergroup relations in the workplace. All scale scores were high and well above the mid-point of the scale, which suggests that the multicultural climate, integration orientation and employee attitude were experienced by these employees as favourable and that they were satisfied with what they experience. White employees seemed to experience a slightly more favourable working environment, although the differences were very small and are only significant for ethnic vitality, individual integration acculturation orientation, ethnic integration and subjective experiences of work success.

\section{Discussion}

A model of multiculturalism in South African workplace is proposed and tested. The model holds that diversity can be conceptualised as an interrelated set of a multicultural climate (as an antecedent), ethnic integration (as a mediator) and employee attitudes (as outcomes). The model was confirmed in groups of all black, mixed race and white employees. Models of multiculturalism have been reported in the literature (Jackson et al., 2012). These results concur with recent findings (Jackson et al., 2012), suggesting that (in this sample) a perceived multiculturalism climate was related to ethnic integration and positive attitudes at work. Employees who experienced more multiculturalism at work also reported higher ethnic integration and better employee attitudes at work. We can therefore conclude that the model of multiculturalism in the workplace is a valid conceptualisation of diversity in the workplace because it was demonstrated that multiculturalism and tolerance matter for ethnic vitality and ethnic integration as well as employee attitudes at work. Moreover, it was found that the link between a multicultural climate and outcomes is fully mediated by ethnic integration. The mediating effect of ethnic integration was also supported in a recent empirical study (Jackson et al., 2012) that tested a simplified version of the current model as well as a dual process model of diversity (Jackson et al., 2013b, Jackson \& Van de Vijver, 2018). This simplified model (Jackson et al., 2012) does include all the current multicultural climate antecedents (multicultural norms or practices and tolerance) but did not include ethnic vitality as part of ethnic integration latent factor as mediator and include ill health (as opposed to job satisfaction and organisation commitment in the current contribution) as a psychological acculturation outcome. From a conceptual perspective, this model implies that the more distal variable of a multicultural climate influences employee attitudes through a set of more proximal integration attitudes and practices. From a theoretical perspective, it is therefore argued that the current model emphasises the inclusion of ethnic vitality as an additional element to the ethnic integration mediating latent factor.

Lastly, it was hypothesised that significant differences would be observed between black, mixed race and white ethnic groups in South Africa, employed in the South African workplace, in actual experiences of multiculturalism and

TABLE 5: Means and standard deviations per scale for the different ethnic groups.

\begin{tabular}{|c|c|c|c|c|c|c|c|c|c|}
\hline \multirow[t]{2}{*}{ Variables } & \multicolumn{2}{|c|}{ White groups (1)† } & \multicolumn{2}{|c|}{ Black groups (2)\$ } & \multicolumn{2}{|c|}{ Mixed race $(3) \S$} & \multicolumn{3}{|c|}{ Cohen's $d$} \\
\hline & $M$ & $S D$ & $M$ & $S D$ & $M$ & $S D$ & $1 / 2$ & $1 / 3$ & $2 / 3$ \\
\hline \multicolumn{10}{|l|}{ Multicultural antecedents } \\
\hline Multicultural norms & 3.32 & 0.63 & 3.25 & 0.79 & 3.31 & 0.67 & 0.09 & 0.02 & 0.08 \\
\hline Multicultural practices & 3.74 & 0.68 & 3.65 & 0.62 & 3.70 & 0.73 & 0.13 & 0.06 & 0.09 \\
\hline Tolerance & 3.47 & 0.57 & 3.32 & 0.62 & 3.40 & 0.66 & 0.249 & 0.11 & 0.12 \\
\hline \multicolumn{10}{|l|}{ Multicultural mediators } \\
\hline Ethnic integration demands at work & 3.68 & 0.68 & 3.49 & 0.69 & 3.73 & 0.70 & 0.289 & 0.07 & $-0.34 \uparrow$ \\
\hline Individual integration orientation & 3.96 & 0.62 & 3.68 & 0.84 & 3.78 & 0.74 & 0.339 & $0.24 \pi$ & 0.12 \\
\hline \multicolumn{10}{|l|}{ Employee attitudes: Outcomes } \\
\hline Job satisfaction & 3.38 & 0.59 & 3.27 & 0.54 & 3.22 & 0.65 & $0.24 \uparrow$ & 0.259 & 0.08 \\
\hline Organisation commitment & 3.72 & 0.73 & 3.67 & 0.79 & 3.66 & 0.63 & 0.06 & 0.08 & 0.01 \\
\hline Subjective experiences of work success & 3.99 & 0.54 & 3.80 & 0.53 & 3.87 & 0.55 & 0.359 & 0.239 & 0.13 \\
\hline
\end{tabular}

$\dagger, N=77 ; \$, N=109 ; \S, N=113$

厂, $d \geq 0.20$ (small effect).

$\mathrm{M}$, means; SD, standard deviation. 
mainstream tolerance, ethnic vitality, ethnic integration and positive employee attitudes. The findings suggest that white employees experienced higher on multicultural norms and practices as well as tolerance and ethnic vitality at work, and preferred an individual integration acculturation orientation and subjective experiences of work success and more at work compared to black and mixed race employees in this study. This finding could be because of the fact that white employees still occupy the dominant position in the economic sphere of the South African society, especially in the private sector as confirmed by the most recent Employment Equity Report issued by the South African Department of Labour (Department of Labour, 2017). Only negligible differences to small effect sizes were observed. Therefore, even though white employees tended to show somewhat higher scores on the antecedent, mediating and outcome variables, the group differences are small. All dimension scores are high and well above the mid-point of the scale, which suggests that the multicultural climate, ethnic integration orientations and employee attitudes that are experienced by these employees are favourable. Practically speaking, it means that the employees are satisfied with what they experience. The results concur with previous findings that suggest that white employees seem to experience a slightly more favourable multicultural environment (Jackson et al., 2012). In addition, the organisational literature suggests that minorities encounter less favourable racial conditions in firms than their white counterparts (Foley, Kidder, \& Powell, 2002; Greenhaus, Parasuraman, \& Wormley, 1990). Minorities also reported such concerns to be of greater relative importance (Kossek \& Zonia, 1993; Mor Barak, Cherin, \& Berkman, 1998). In turn, these negative racial conditions have been shown to undermine minorities' organisational attitudes (Chrobot-Mason, 2003; Foley et al., 2002).

There is some literature, originating from Western countries, about the question of whether diverse teams are more productive or less productive than monocultural teams (e.g. Bowers, Pharmer, \& Salas, 2000; Van Knippenberg, De Dreu, \& Homan, 2004; Webber \& Donahue, 2001). This question is of theoretical interest; yet, its practical interest for multicultural countries like South Africa is limited as the cultural composition of work teams can usually not be manipulated and more and more teams are multicultural. In such countries, it has more practical relevance to study the factors that can enhance well-being and productivity of employees in such organisations. In addition, the Employment Equity Act (RSA, 1998) recommends that designated employer must collect information and conduct an analysis, as prescribed, of its employment policies, practices, procedures and the working environment, in order to identify employment barriers that adversely affect people from designated groups. The proposed model and instrument could useful for such workplace analysis or diversity audits. This study successfully demonstrated that both a multicultural climate (and conditions conducive for such a climate) and an inclusive orientation of employees have a substantial impact on employee attitudes. It may be noted that various aspects of this model (both in multicultural climate and in ethnic integration) can be influenced by diversity policies. This submission highlights the importance of treating all with respect and dignity in the workplace and provides a tool for $\mathrm{HR}$, as the custodian of human right in the workplace, to 'frequently' assess especially intercultural interaction in the workplace.

\section{Limitations}

The current study has some limitations. The cross-sectional nature of the data used does not allow for rigorous testing of causal links between the variables at hand; therefore, the dynamicnature of the relationships between multiculturalism, ethnic integration and employee attitudes cannot be uncovered with total accuracy. However, the findings constitute a useful basis for considering further research into factors that influence employees' attitudes. One also needs to consider that the use of a self-report method may be a limitation of the study. We cannot be certain that self-report measures provide an accurate picture of employees' actual responses to multiculturalism, ethnic integration and employee attitudes.

Future empirical work could consider the role of demographic variables such as age, gender, socio-economic status with regard to the support for multiculturalism, ethnic integration and its impact on employee attitudes in the workplace. Future studies should also consider using longitudinal designs and recruiting samples from various other state departments in the public sectors as well as various organisations from various sectors in the private sector and not for profit organisations, using mixed methods and according to Adkoli (2017, p. 38) multiple methods, tools and techniques, such as grounded theory (to develop a theoretical model based on actual ground realities), phenomenology (to understand a phenomenon from participants' perception), ethnography (to gain insights in the organisation culture), case studies (to develop in-depth understanding of a case) and narratives (to capture long personal experience). It is advised that researchers interact with the participant in a 'naturalistic setting' as opposed to an artificial 'lab setting' and helps in describing and exploring an issue to 'contextualisation' rather than 'generalisation'. A method of 'triangulation' should be used for validating the results. This will facilitate the use of the correct context-specific interventions.

\section{Recommendations}

While diversity management is an approach that revolves around employees, the human resource management (HRM) function is the custodian of the people management processes. The HRM toolkits addressing inequality in recruitment, appraisal, advancement and reward can enhance equal employment opportunity, improve inclusiveness and enhance creativity in a diverse workforce. It is therefore widely recognised by researchers that effective diversity management can be achieved through using appropriate HRM strategies (Shen, Chanda, D'Netto, \& Monga, (2009). 
At a theoretical level, diversity research has been criticised for lacking scientific precision, theoretical analysis, historical specificity, empirical grounding and for being seriously under-researched (Litvin 1997; Nkomo \& Cox 1996; Sanchez \& Brock 1996). In this regard, Gedro and Mizzi (2014, p. 452) suggest critically exploring human resource development through a queer theory lens. Firstly, this perspective would mean that the structures of organisations must questioned in ways that are very real and very practical to all workers. This suggestion could manifest in human resources development (HRD) practices in the following ways: through the selection, which includes the opportunities for preparation, or 'grooming' such as stretch assignments and expatriate assignments (Gedro, 2010) for promotional opportunities; through the design of mentoring and career development programmes; through the design of workplace learning initiatives; through organisational change and development endeavours and through HR policies. Examining and then changing HRD practices to reduce or even eliminate inherent biases against minorities have the potential to shift an organisational culture from one of heteromasculine dominance to one that operates on principles of inclusion, respect and awareness of differences. Career development programmes that take into account the tapestry, the complexity and the fluidity of identity are one way of operationalising queer and feminist theoretical principles. To be more specific, career development programmes that resist stereotyping people based upon their gender or gender expression or their (perceived) sexual orientation or rather that expand the range of possibilities present a helpful type of resistance to fixed, stable and oppressive categories of identity.

At a practical level, it is recommended that organisations make use of cross-cultural training as intervention, which aims to develop the awareness, knowledge and skills needed to interact appropriately and effectively with culturally diverse customers and co-workers, which is an important element in the development of cultural competence (Bean, 2006). The Kraiger, Ford and Salas's (1993) framework of training evaluation identified three learning outcomes: affectivebased, cognitive-based and skill-based outcomes. Kraiger et al. (1993) defined affective-based outcomes as measures of internal states that drive perception and behaviour. Affectivebased outcomes include attitudes, self-efficacy and motivation in general; and cognitive-based outcomes include verbal knowledge, knowledge organisation and cognitive strategies. Skill-based outcomes include changes in behaviour (Kraiger et al., 1993). Kulik and Roberson (2008) have suggested that there are stronger effects for diversity training focused on dissemination (cognitive-based) and skills training than on awareness (affective-based). However, Kalinoski et al. (2013) observed in their meta-analysis of 65 studies for diversity training weaker effects on affectivebased outcomes, compared with effects observed on cognitive-based and skill-based outcomes.

Forming teams with members from different cultures should be encouraged (contact hypothesis) and the inconsistent application policies should be discouraged as it could create impressions and perceptions of discrimination. The findings seem to suggest that multiculturalism works and it even economically pays off by creating a climate that creates a sense of subjective experience of work success. Lastly, it is suggested that organisations ensure that they have diversity management policies in place that can consistently be applied in situations where employees show disrespect for others' cultural practices or undermine multicultural practices in the workplace.

\section{Conclusion}

The future success of South Africa's unique democracy depends on the development of harmonious race relations. Workplaces in South Africa represent microcosms of the society. The development of models and frameworks that could assist to analysis race relations at work should be encouraged. The use of such models that enhance harmonious race relations at work could go a long way in understanding race-related dynamics in the broader society. Understanding the factors underlying interracial attitudes is consequently important (Gordon, 2017). This model provides a basis for emphasising the importance of the role of multicultural norms, conventions and practices (culture) in shaping positive inter cultural orientations and employee attitudes at work.

\section{Acknowledgements Competing interests}

The authors declare that they have no competing interests with regard to the writing of this article.

\section{Authors' contributions}

L.T.B.J. was responsible for data collection, literature review, statistical analyses, article review and submission. F.J.R.V.d.V. was responsible for review and advice on matters relating to the literature, statistical analyses and final article.

\section{Reference}

Adelman, M. B. (1988). Cross-cultural adjustment: A theoretical perspective on socia support. International Journal of Intercultural Relations, 12, 183-205. https://doi. org/10.1016/0147-1767(88)90015-6

Adkoli, B. V. (2017). Educational research in health sciences. Journal of Education Technology in Health Sciences, 4(2), 38-41. https://doi.org/10.18231/23938005.2017.0011

Ait Ouarasse, O., 2004, What immigration does to young people: The psychological acculturation of Moroccans in the Netherlands. Unpublished doctoral dissertation, Tilburg University, Tilburg, The Netherlands.

Ait Ouarasse, O., \& Van de Vijver, F. J. R. (2004). Structure and function of the perceived acculturation context of young Moroccans in the Netherlands. International Journal of Psychology, 39, 190-204. https://doi. org/10.1080/00207590344000367

Alsheh, Y., \& Elliker, F. (2015). The art of becoming a minority: Afrikaner re-politicisation and Afrikaans political ethnicity. African Studies, 74(3), 429-448. https://doi.org/ 10.1080/00020184.2015.1011368

Arends-Tóth, J. V., \& Van de Vijver, F. J. R. (2006). Issues in conceptualization and assessment of acculturation. In M. H. Bornstein \& L. R. Cote (Eds.), Acculturation and parent-child relationships: Measurement and development (pp. 33-62). Mahwah, NJ: Erlbaum.

Ashikali, T., \& Groeneveld, S. (2015). Diversity management in public organizations and its effect on employees' affective commitment. Review of Public Personnel Administration, 35(2), 146-168, https://doi.org/10.1177/0734371X13511088 
Badgett, M. V. L. (1996). Employment and sexual orientation: Disclosure and discrimination in the workplace. Journal of Gay \& Lesbian Social Services, 4 29-52. https://doi.org/10.1300/J041v04n04_03

Barry, B. (2001). Culture and equality: An egalitarian critique of multiculturalism. Cambridge: Polity.

Baumeister, R. F., \& Leary, M. R. (1995). The need to belong: Desire for interpersonal attachments as a fundamental human motivation. Psychological Bulletin, 117, 497-529. https://doi.org/10.1037/0033-2909.117.3.497

Bean, R. (2006). The effectiveness of cross-cultural training in the Australian context. Report prepared for the Department of Immigration and Multicultural Affairs on behalf of the Joint Commonwealth, State and Territory Research Advisory Committee. Canberra, Australia: Cultural Diversity Services.

Berry, J. W. (1994). Multicultural policy in Canada: A social psychological analysis. Canadian Journal of Behavioural Sciences, 16, 353-370. https://doi.org/10.1037/h0080859

Berry, J. W. (1997). Immigration, acculturation, and adaptation. Applied Psychology: An International Review, 46, 5-68. https://doi.org/10.1080/026999497378467

Berry, J. W. (2003). Conceptual approaches to acculturation. In K. Chun, P. BallsOrganista, \& G. Martin (Eds.), Acculturation: Advances in theory, measurement, and applied research (pp. 17-37). Washington DC: American Psychological and applied research (pp. 17-37). Washington DC:
Association Press. http://dx.doi.org/10.1037/10472-004

Berry, J. W. (2006). Mutual attitudes among immigrants and ethnocultural groups in Canada. International Journal of Intercultural Relations, 30, 719-734. https://doi. org/10.1080/01973530903540067

Berry, J. W. (2001). A psychology of immigration. Journal of Social Issues, 57(3), 615-631.

Berry, J. W. (2005). Acculturation: Living successfully in two cultures. International Journal of Intercultural Relations, 29(6), 697-712.

Berry, J. W. (2008). Globalisation and acculturation. International Journal of Intercultural Relations, 32(4), 328-336.

Berry, J. W. (2011). Integration and multiculturalism: Ways towards social solidarity. Papers on Social Representations, 20(1), 2.1-2.21.

Berry, J. W. (2013). Achieving a global psychology. Canadian Psychology/psychologie canadienne, 54(1), 55.

Berry, J. W., \& Kalin, R. (1995). Multicultural and ethnic attitudes in Canada: An overview of the 1991 national survey. Canadian Journal of Behavioural Science/ Revue canadienne des sciences du comportement, 27(3), 301

Berry, J. W., Poortinga, Y. H., Breugelmans, S. M., Chasiotis, A., \& Sam, D. L. (2011). Cross-cultural psychology: Research and applications. New York: Cambridge University Press

Blaser, T. M., \& Van der Westhuizen, C. (2012). Introduction: The paradox of postapartheid 'Afrikaner' identity: Deployments of ethnicity and neo-liberalism. African Studies 71(3), 380-390. https://doi.org/10.1080/00020184.2012.740882

Booysen, L. A. E., \& Nkomo, S. M. (2010). Gender role stereotypes and requisite management characteristics: The case of South Africa. Gender in Management: An International Journal, 25(4), 285-300. https://doi.org/10.1108/ 17542411011048164

Bourhis, R. Y., Moïse, L. C., Perreault, S., \& Senécal, S. (1997). Toward an interactive acculturation model: A social psychological approach. International Journal of Psychology, 32, 369-386. https://doi.org/10.1080/002075997400629

Bowers, C. A., Pharmer, J. A., \& Salas, E. (2000). When member homogeneity is needed in work teams. A meta-analysis. Small Group Research, 31, 305-327. https://doi.org/10.1177/104649640003100303

Burns, N., \& Grove, S. K. (1993). The practice of nursing research, conduct, critique, and utilisation. (2nd edn.). Oxford: W.B. Saunders.

Cashmore, E. (2003). Sport psychology: The key concepts (2nd edn.). London, New York: Routledge Taylor \& Francis.

Cheung, G. W., \& Rensvold, R. B. (2002). Evaluating goodness-of-fit indexes for testing measurement invariance. Structural Equation Modeling, 9, 233-255. https://doi. org/10.1207/S15328007SEM0902_5

Cho, S., \& Mor Barak, M. E. (2008). Understanding of diversity and inclusion in a perceived homogeneous culture: A study of organizational commitment and job performance among Korean employees. Administration in Social Work, 32(4), 100-126. https://doi.org/10.1080/03643100802293865

Choi, S., \& Rainey, H. G. (2010). Managing diversity in US federal agencies: Effects of diversity and diversity management on employee perceptions of organizational
performance. Public Administration Review, 70(1), 109-121. https://doi. performance. Public Administration
org/10.1111/j.1540-6210.2009.02115.x

Chrobot-Mason, D. L. (2003). Keeping the promise: Psychological contract violations for minority employees. Journal of Managerial Psychology, 18, 22-45. https://doi. for minority employees. Journal of
org/10.1108/02683940310459574

Corneo, G., \& Olivier, J. (2009). A theory of tolerance. Journal of Public Economics, 93(5), 691-702. https://doi.org/10.1016/j.jpubeco.2009.02.005

Cox, T., Jr. (1993). Cultural diversity in organizations: Theory, research, and practice. San Francisco, CA: Berrett-Koehler.

Cox, T., \& Blake, S. (1991). Managing cultural diversity: Implications for organizational competitiveness. Academy of Management Executive, 5(3), 45-56. https://doi. org/10.5465/AME.1991.4274465

Drydakis, N., MacDonald, P., Chiotis, V., \& Somers, L. (2018). Age discrimination in the UK labour market. Does race moderate ageism? An experimental investigation. Applied Economics Letters, 25(1), 1-4. https://doi.org/1080/13504851.2017.1290763

Durrheim, K. (2010). Attitudes towards racial redress in South Africa. In Roberts, B., Kivilu, M. wa, \& Davids Y. D. (Eds.), South African social attitudes: 2nd report (pp. 31-42). Cape Town, South Africa: HSRC Press.
Durrheim, K., \& Talbot, K. (2012). The Princeton trilogy revisited: How have racial stereotypes changed in South Africa? South African Journal of Psychology, 42(4), 476-491. https://doi.org/10.1177/008124631204200403

Earley, C. P., \& Mosakowski, E. (2000). Creating hybrid team cultures: An empirical test of transnational team functioning. Academy of Management Journal, 43, 26-49.

Fernandez, J. P. (1991). Managing a diverse workforce. Lexington, MA: Lexington Books.

Florida, R. (2003). Cities and the creative class. City \& Community, 2(3), 3-19. https:// doi.org/10.1111/1540-6040.00034

Foley, S., Kidder, D. L., \& Powell, G. N. (2002). The perceived glass ceiling and justice perceptions: An investigation of Hispanic law associates. Journal of Management, 28, 471-496. https://doi.org/10.1177/014920630202800401

Franken, S. (2015). Personal: Diversity management. Wiesbaden, Germany: Springer Gabler.

Frederickson, G. M. (1997). Models of American ethnic relations: A historical perspective. In D. A. Prentice \& D. T. Miller (Eds.). Cultural divides: Understanding and overcoming group conflict (pp. 23-34). New York: Russell Sage Foundation.

Galchenko, I. (2006). Acculturation of Russian Immigrants and Emigrants. Unpublished doctoral dissertation, Tilburg University. Veenendaal, the Netherlands: Universal Press.

Gedro, J. (2010). The lavender ceiling atop the global closet: Human resource development and lesbian expatriates. Human Resource Development Review 9(4), 385-404.

Gedro, J., \& Mizzi, R. C. (2014). Feminist theory and queer theory: Implications for HRD research and practice. Advances in Developing Human Resources, 16 (4), 445-456.

Gibson, J. L. (2006). Overcoming apartheid: Can truth reconcile a divided nation? The Annals of the American Academy of Political and Social Science, 603(1), 82-110.

Goodhart, D. (2013). The British dream: Successes and failures of post-war immigration. London: Atlantic Books.

Gordon, S. L. (2017). Understanding semantic differential measures in modern South Africa: Attitudes of Black Africans towards White South Africans. South African Journal of Psychology. https://doi.org/10.1177/0081246317725921

Greenhaus, J. H., Parasuraman, S., \& Wormley, W. M. (1990). Effects of race on organizational experiences, job performance evaluations, and career outcomes. Academy of Management Journal, 33, 64-86. https://doi.org/10.2307/256352

Gustafsson, A., \& Bowen, D. E. (2017). The curious case of interdisciplinary research deficiency: Cause or symptom of what truly ails us?. Journal of Business Research 79, 212-218. https://doi.org/10.1016/j.jbusres.2017.05.006

Harter, J. K., Schmidt, F. L., \& Hayes, T. L. (2002). Business-unit-level relationship between employee satisfaction, employee engagement, and business outcomes: A meta-analysis. Journal of Applied Psychology, 87, 268-279. https://doi. org/10.1037/0021-9010.87.2.268

Harwood, J., Giles, H., \& Bourhis, R. Y. (1994). The genesis of vitality theory: Historical patterns and discoursal dimensions. International Journal of the Sociology of Language, 108, 167-206. https://doi.org/10.1515/ijsl.1994.108.167

Herman, D. (2000). The counter side of affirmative action. Pretoria, South Africa: Jotha.

Hofmeyr, J. H. (2006, November). Report of the Sixth Round of the SA Reconciliation Barometer Survey. Wynberg, South Africa: Institute for Justice and Reconciliation.

Howarth, C., \& Andeouli, E. (in press). Has multiculturalism failed? The importance of lay knowledge and everyday practice. London, England: The London School of Economics and Political Science Publications. Retrieved from http://centremcd. Economics and Political Science Publications. Retrieved from http://centremcd.
uqam.ca/upload/files/Publications/Veille/has\%20multiculturalism\%20failed.pdf

Hui, B. P. H., Chen, S. X., Leung, C. M., \& Berry, J. W. (2015). Facilitating adaptation and intercultural contact: The role of integration and multicultural ideology in dominant and non-dominant groups. International Journal of Intercultural Relations, 45, 70-84. https://doi.org/10.1016/j.jijintrel.2015.01.002

Institute for African Culture and International Understanding (IACIU) (2014). Culture and Economic Security in Africa: Remodeling the Options, vol. 3. Abeokuta, Nigeria: Olusegun Obasanjo Presidential Library.

Jackson, L. T., \& van de Vijver, F. J. (2018). Confirming the Structure of the Dual Process Model of Diversity amongst Public Sector South African Employees. Journal of Psychology in Africa, 28(3), 182-191.

Jackson, L. T. B., Van de Vijver, A. J. R., \& Ali, S. (2012). Positive acculturation conditions and well-being in a mine in the North-West province. South African Journal of Industrial Psychology, 38(1), 38-48. https://doi.org/10.4102/sajip.v38i1.997

Jackson, L. T. B., Van de Vijver, A. J. R., \& Burckard, A. (2011). Adverse acculturation conditions and well-being of mine employees in the North-West Province. Journa of Psychology in Africa, 21, 385-396. https://doi.org/10.1080/14330237.2011.10 820472

Jackson, L. T. B., Van de Vijver, F. J. R., \& Biela, R. (2013a). Coping with diversity in dormitories in a historically white $\mathrm{HEl}$ in South Africa. South African Journal of Higher Education, 27(3), 607-626.

Jackson, L. T., Van de Vijver, F. J., \& Molokoane, D. H. (2013b). A dual-process model of diversity outcomes: The case South African police service in the Pretoria area. SA Journal of Human Resource Management, 11(1), 13.

Jaga, A., Arabandi, B., Bagraim, J., \& Mdlongwa, S. (2017). Doing the 'gender dance' Black women professionals negotiating gender, race, work and family in postapartheid South Africa. Community, Work \& Family, 31(1), 1-16. https://doi.org/1 $0.1080 / 13668803.2017 .1311840$

James, E. H., Brief, A. P., Dietz, J., \& Cohen, R. R. (2001). Prejudice matters: understanding the reactions of Whites to affirmative action programs targeted to benefit Blacks. Journal of Applied Psychology, 86(6), 1120. 
Johnston, E. R. (2015). South African clinical psychology's response to cultura diversity, globalisation and multiculturalism: A review. South African Journal of diversity, globalisation and multiculturalism: A review. South African Journ
Psychology, 45(3), 374-385. https://doi.org/10.1177/0081246315575648

Joubert, Y. T. (2017). Workplace diversity in South Africa: Its qualities and management. Journal of Psychology in Africa, 27, 367-371. https://doi.org/10.1080/14330237. 2017.1347760

Jovchelovitch, S. (2007). Knowledge in context: Representations, community and culture. New York: Routledge.

Kalinoski, Z. T., Steele Johnson, D., Peyton, E. J., Leas, K. A., Steinke, J., \& Bowling, N. A (2013). A meta analytic evaluation of diversity training outcomes. Journal of Organizational Behavior, 34(8), 1076-1104. https://doi.org/10.1002/job.1839

Khoza, R. (1993). The need for an African approach to management. Randburg, South Africa: Knowledge Resources.

Kossek, E. E., \& Zonia, S. C. (1993). Assessing diversity climate: A field study of reactions to employer efforts to promote diversity. Journal of Organizational Behavior, 14, 61-81. https://doi.org/10.1002/job.4030140107

Kraiger, K., Ford, J. K., \& Salas, E. (1993). Application of cognitive, skill-based, and affective theories of learning outcomes to new methods of training evaluation. Journal of Applied Psychology, 78, 311-328. https://doi.org/10.1037/0021 9010.78.2.311

Kukathas, C. (2003). The liberal archipelago. A theory of diversity and freedom. Oxford: Oxford University Press.

Kulik, C. T., \& Roberson, L. (2008). Diversity initiative effectiveness: What organizations can (and cannot) expect from diversity recruitment, diversity training, and formal mentoring programs. In A. P. Brief (Ed.). Diversity at work (pp. 265-317). Cambridge: Cambridge University Press.

Litvin, D. R. (1997). The discourse of diversity: From biology to management Organization, 4(2), 187-209.

MacCallum, R. C., Roznowski, M., \& Necowitz, L. B. (1992). Model modifications in covariance structure analysis: The problem of capitalization on chance. Psychological bulletin, 111(3), 490. https://doi.org/10.1037/0033-2909.111.3.490

Malewska-Peyre, H. (1982). L' experience du racisme et de la xenophobie chez jeunes immigres [The experience of racism and xenophobia among young immigrants]. In H. Malewska-Peyre (Ed.), Crise d'identite et deviance chez jeunes immigres [Identity crisis and deviance among young immigrants] (pp. 53-73). Paris: La Documentation Francaise.

Mason, A. (2018). The critique of multiculturalism in Britain: Integration, separation and shared identification. Critical Review of International Social and Political Philosophy, 21(1), 22-45. https://doi.org/10.1080/13698230.2017.1398444

Mazibuko, J. V., \& Govender, K. K. (2017). Exploring workplace diversity and organisational effectiveness: A South African exploratory case study. SA Journal of Human Resource Management, 15, 10. https://doi.org/10.4102/sajhrm.v15i0.865

McKay, P. F., Avery, D. R., Tonidandel, S., Morris, M. A., Hernandez, M., \& Hebl, M. R. (2007). Racial differences in employee retention: Are diversity climate perception the key? Personnel Psychology, 60, 35-62. https://doi.org/10.1111/j.1744 6570.2007.00064.x

Moloto, G. R. B., Brink, L., \& Nel, J. A. (2014). An exploration of stereotype perceptions amongst support staff within a South African higher education institution. South African Journal of Human Resource Management, 12(1), 1-12. https://doi. org/10.4102/sajhrm.v12i1.573

Mor Barak, M. E., Cherin, D. A., \& Berkman, S. (1998). Organizational and personal dimensions in diversity climate: Ethnic and gender differences in employee perceptions. Journal of Applied Behavioral Science, 34, 82-104. https://doi. org/10.1177/0021886398341006

Morrison, A. M., \& Von Glinow, M. A. (1990). Women and minorities in management. American Psychologist, 45, 200-208. https://doi.org/10.1037/0003066X.45.2.200

Moscovici, S. (1973). Foreword. In C. Herzlich (Ed.), Health and illness: A social psychological analysis (pp. ix-xiv). London: Academic Press [for] the European Association of Experimental Social Psychology.

Moscovici, S. (2000). The phenomenon of social representations. In G. Duveen (Ed.) Social representations: Explorations in social psychology (pp. 1-17). Cambridge: Social represer
Polity Press.

Nishii, L. H. (2013). The benefits of climate for inclusion for gender-diverse groups. Academy of Management Journal, 56, 1754-1774. https://doi.org/10.5465/ amj.2009.0823

Nkomo, S., \& Cox Jr, T. (1996). Diverse identities in organizations. In S. Clegg, C. Hardy, \& W. Nord (eds.), Handbook of Organization Studies. (pp. 338-356). London: Sage.

Nunnally, J. C., \& Bernstein, I. H. (1994). Psychometric theory (3rd edn.). New York: McGraw-Hill.

Ojukwu, C., \& Oni, E. O. (2017). Multiculturalism, racialism and the dilemma of the African-American in the twenty-first century. AFFRIKA Journal of Politics, Economics and Society, 7(1), 111-126.

Okin, S. (1999). Is multiculturalism bad for women? In J. Cohen, M. Howard \& M. Nussbaum (Eds.), Is multiculturalism bad for women? (pp. 8-24). Princeton, NJ: Princeton University Press.

Olanrewaju, I. P., Loromeke, R. E., \& Adekoye, R. A. (2017). Multiculturalism, value differences and cross-cultural conflict in Nigeria: Surgery on a centenarian. Journa of African Union Studies, 6(1), 39-62.

O'Leary, V. E., \& Ickovics, J. R. (1992). Cracking the glass ceiling: Overcoming isolation and discrimination. In U. Sekeran \& F. Leong (Eds.), Womanpower: Managing in times of demographic turbulence (pp. 7-30). Beverly Hills, CA: Sage.
Penhaligon, N. L., Louis, W. R., \& Restubog, S. L. D. (2013). Feeling left out? The mediating role of perceived rejection on workgroup mistreatment and affective, behavioral, and organizational outcomes and the moderating role of organizational norms. Journal of Applied Social Psychology, 43, 480-497. https://doi. org/10.1111/j.1559-1816.2013.01026.x

Pham, T. B., \& Harris, R. J. (2001). Acculturation strategies among VietnameseAmericans. International Journal of Intercultural Relations, 25, 279-300. https:// doi.org/10.1016/S0147-1767(01)00004-9

Plaut, V. C., Sanchez-Burks, J., Buffardi, L., \& Stevens, F. G. (2007). What about me? Understanding non-minority aversion to diversity initiatives in the workplace. Unpublished manuscript, University of Georgia.

Porter, L. W., Steers, R. M., Mowday, R. T., \& Boulian, P. V. (1974). Organizational commitment, job satisfaction, and turnover among psychiatric technicians. Journal of Applied Psychology, 59, 603-609. https://doi.org/10.1037/h0037335

Ramadan, T. (2010). The quest for meaning: Developing a philosophy of pluralism. London: Penguin Group.

Ramakrishna, D. (2013). Multiculturalism in America, Australia and India. Socia Change, 43(1), 99-110. https://doi.org/10.1177/0049085713475729

Rhoades, L., \& Eisenberger, R. (2002). Perceived organizational support: a review of the literature. Journal of applied psychology, 87(4), 698.

Rosado, C. (1996). Toward a definition of multiculturalism. Retrieved from http:// rosado.net/pdf/Def_of_Multiculturalism.pdf

RSA (Republic of South Africa). (1995). Labour Relations Act, Act No. 66 of 1995. Retrieved from http://www.info.gov.za/acts/1995/a66-95.pdf

RSA (Republic of South Africa). (1996). Constitution of South Africa, Act No.108 of 1996. Retrieved from http://www.info.gov.za/documents/constitution/1996/a108-96.pdf

RSA (Republic of South Africa). (1997a). Basic Conditions of Employment Act, Act No 75 of 1997. Retrieved from http://www.info.gov.za/view/DownloadFileAction?id=70820

RSA (Republic of South Africa). (1997b). Employment Equity Act, Act No. 55 of 1998. Retrieved from https://www.labour.gov.za/downloads/legislation/acts/employmentequity/Act $\% 20-\% 20$ Employment $\% 20$ Equity.pdf

RSA (Republic of South Africa). 1998. Employment Equity Act, Act No. 55 of 1998. Retrieved from http://www.labour.gov.za/DOL/downloads/legislation/acts/ employment-equity/eegazette2015.pdf

Department of Labour (DoL) (2017). 18th Commission for Employment Equity Annual Report 2017-2018. Pretoria: Government Printers. Retrieved from http://www. labour.gov.za/DOL/documents/annual-reports/Commission\%20for\%20Employment $\%$ 20Equity\%20Report/2017-2018/downloads/documents/annual-reports/employmentequity/2017-2018/18ceereport_amended.pdf

Sahin, Ç. (2011). Perceptions of prospective teachers about tolerance education. Educational Research and Reviews, 6, 77-86.

Sam, D. L. (2006). Acculturation and health. In Sam, D. L., \& Berry, J. W. (Eds.). (2006). The Cambridge Handbook of Acculturation Psychology, (pp. 452-468). Cambridge: Cambridge University Press.

Sanchez, J. I., \& Brock, P. (1996). Outcomes of perceived discrimination among Hispanic employees: is diversity management a luxury or a necessity?. Academy of Management Journal, 39(3), 704-719.

Seeman, T. E. (1996). Social ties and health: The benefits of social integration. Annals of Epidemiology, 6(5), 442-451.

Shen, J., Chanda, A., D'Netto, B., \& Monga, M. (2009). Managing diversity through human resource management: An international perspective and conceptua framework. The International Journal of Human Resource Management, 20(2), 235-251. https://doi.org/10.1080/09585190802670516

Shen, J., Chanda, A., D'Netto, B., \& Monga, M. (2015). Managing diversity through human resource management: An international perspective and conceptual framework. The International Journal of Human Resource Management, 20 235-251. https://doi.org/10.1080/09585190802670516

Shore, L. M., Cleveland, J. N., \& Sanchez, D. (2018). Inclusive workplaces: A review and model. Human Resource Management Review, 28(2), 176-189.

Shore, L. M., Randel, A. E., Chung, B. G., Dean, M. A., Holcombe Ehrhart, K., Singh, G. (2011). Inclusion and diversity in work groups: A review and model for future
research. Journal of Manage, 37(4), 1262-1289. https://doi.org/10.1177 research. Journal of
/0149206310385943

Skaalvik, E. M., \& Skaalvik, S. (2011). Teacher job satisfaction and motivation to leave the teaching profession: Relations with school context, feeling of belonging, and emotional exhaustion. Teaching and Teacher Education, 27, 1029-1038. https:// emotional exhaustion. Teaching and
doi.org/10.1016/j.tate.2011.04.001

Steyn, M. (2004). Rehabilitating a Whiteness Disgraced: Afrikaner white talk in PostApartheid South Africa. Communication Quarterly, 52(2), 143-169. https://doi. org/10.1080/01463370409370187

Steyn, M., \& Foster, D. (2008). Repertoires for talking white: Resistant whiteness in Post-Apartheid South Africa. Ethnic and Racial Studies, 31(1), 25-51. https://doi. org $/ 10.1080 / 01419870701538851$

Stoermer, S., Bader, A. K., \& Froese, F. J. (2016). Culture matters: The influence of national culture on inclusion climate. Cross Cultural \& Strategic Management, 23, 287-305. https://doi.org/10.1108/CCSM-11-2014-0135

Stoermer, S., Hitotsuyanagi-Hansel, A., \& Froese, F. J. (2017). Racial harassment and job satisfaction in South Africa: The moderating effects of career orientations and managerial rank. The International Journal of Human Resource Management, 1-20. https://doi.org/10.1080/09585192.2016.1278254

Sue, D. W., \& Capodilupo, C. (2008). Racial, gender, and sexual orientation microaggressions: Implications for counseling and psychotherapy. In D. W. Sue \& D. Sue (Eds.), Counseling the culturally diverse: Theory and practice (pp. 105-130). Hoboken, NJ: John Wiley \& Sons. 
Thoits, P. A. (2011). Mechanisms linking social ties and support to physical and mental health. Journal of Health and Social Behavior, 52, 145-161. https://doi. org/10.1177/0022146510395592

Thomas, D., \& Ely, R. E. (1996). Making differences matter: A new paradigm for managing diversity. Harvard Business Review, 74, 79-90.

Trivedi, P. (2008). Respecting diversity through acknowledging, valuing and using diversity and challenging inequalities. Chichester: Wiley Online Library. https:// doi.org/10.1002/9780470699300.ch4

Tropp, L. R., Hawi, D. R., O'Brien, T. C., Gheorghiu, M., Zetes, A., \& Butz, D. A. (2017) Intergroup contact and the potential for post-conflict reconciliation: Studies in Northern Ireland and South Africa. Peace and Conflict: Journal of Peace Psychology, 23(3), 239-249. https://doi.org/10.1037/pac0000236

Van de Vijver F. J. R., Breugelmans, S. M., \& Schalk-Soekar, S. R. G. (2008) Multiculturalism: Construct validity and stability. International Journal of Intercultural Relations, 32, 93-104. https://doi.org/10.1016/j.ijintrel.2007.11.001

Van der Noll, J., Poppe, E., \& Verkuyten, M. (2010). Political tolerance and prejudice: Differential reactions toward Muslims in the Netherlands. Basic and Applied Social Psychology, 32, 46-56. https://doi.org/10.1080/01973530903540067

Van Knippenberg, D., De Dreu, C. K. W., \& Homan, A. C. (2004). Work group diversity and group performance: An integrative model and research agenda. Journal of

erkuyten, M. (2005). Ethnic group identification and group evaluation among minority and majority groups: Testing the multiculturalism hypothesis. Journal of Personality and Social Psychology, 88, 121-138. https://doi.org/10.1037/0022-3514.88.1.121
Wagner, W., \& Hayes, N. (2005). Everyday discourse and common sense: The theory of social representations. New York: Palgrave MacMillan.

Ward, C., Bochner, S., \& Furnham, A. (2001). The psychology of culture shock (2nd edn.). Philadelphia, PA: Routledge.

Webber, S. S., \& Donahue, L. M. (2001). Impact of highly and less jobrelated diversity on work group cohesion and performance: A meta-analysis. Journal of Management, 27, 141-162. https://doi.org/10.1177/014920 630102700202

Weiss, D. J., Dawis, R. V., England, G. W., \& Lofquist, L. H. (1967). Manual for the Minnesota Satisfaction Questionnaire. Minneapolis, MN: University of Minnesota.

West, E. (2013). The diversity illusion: What we got wrong about immigration and how to set it right. London: Gibson Square Books.

Wooten, L. P., \& James, E. H. (2008). Linking crisis management and leadership competencies: The role of human resource development. Advances in Developing Human Resources, 10(3), 352-379.

Zagefka, H., \& Brown, R. (2002). The relationship between acculturation strategies, relative fit and intergroup relations: Immigrant-majority relations in Germany. European Journal of Social Psychology, 32, 171-188. https://doi.org/10.1002/ ejsp.73

Zimmerman, B. J. (2008). Investigating self-regulation and motivation: Historical background, methodological developments, and future prospects. American Educational Research Journal, 45(1), 166-183. 